\title{
SEVENTH INTERNATIONAL FESTIVAL OF RED CROSS AND HEALTH FILMS, IN VARNA
}

The seventh International Festival of Red Cross and Health Films took place in Varna, Bulgaria, from 16 to 27 June 1977. Held under the auspices of the World Health Organizations (WHO), it was organized by the Bulgarian Red Cross in conjunction with the League of Red Cross Societies. The festival was officially opened by Dr. Kiril Ignatov, Chairman of the Central Committee of the Bulgarian Red Cross. Mr. Marcel Carraud, President of the French Red Cross, spoke on behalf of the League.

The ICRC was represented by Dr. J. de Rougemont, a member of the Committee, Mr. A. Modoux, head of the ICRC's Press and Information Division, and Mr. P. Grand d'Hauteville, regional delegate for Europe.

The Varna festival, organized for the first time in 1965, has become a highly popular worldwide cinema event. It is intended not only to provide for a competition between films on the Red Cross and on health, with awards for the best, but also to stimulate film production in the Red Cross world. The cinema is indeed an ideal means in our time to promote Red Cross and constitutes a very effective instrument for teaching and training.

The screening committee accepted 138 film for showing, from 41countries and five international organizations. Among the prize-winning entries in the "Red Cross films » category were « Bitter Lessons", presented by the USSR, which won the Grand Prix of the President of the Bulgarian Red Cross, and «Faces», presented by the French Red Cross, which received the Grand Prix of the League of Red Cross Societies. Among the films devoted to the popularizing of science, «The Red Cross Drum » (Czechoslovakia), received a gold medal. Three short films, co-produced by the World Health Organization, the International Labour Office and the League of Red Cross Societies, won a silver medal. 
Two other films presenting the activities of international organizations and of National Societies were given awards: "Humanity at Work", from Canada (gold medal) and "Our Symbol, the Squirrel", from Poland (silver medal).

The prize offered by the Committee for the Diffusion of Arts and Letters through the Cinema went to Mr. Marc Gazay, National Director of Information and Public Relations of the French Red Cross and former head of the Office of Information of the League of Red Cross Societies. 